\title{
Evaluation of Soil and Climatic Conditions Supporting Maize (Zea mays L.) Production in Makurdi, Nigeria
}

\author{
S. O. Odoemena ${ }^{1 *}$ and E. A. Igomu ${ }^{1 *}$ \\ ${ }^{1}$ Department of Soil Science, University of Agriculture, Makurdi, Benue State, Nigeria.
}

Authors' contributions

This work was carried out in collaboration between both authors. Author EAI designed the study, performed the statistical analysis, wrote the protocol and the first draft of the manuscript. Author SOO managed the analyses of the study and the literature searches. Both authors read and approved the final manuscript.

Article Information

DOI: $10.9734 / J A E R I / 2017 / 33963$

Editor(s):

(1) El-Sayed Ewis Omran, Soil and Water Department, Faculty of Agriculture, Suez Canal University, Egypt.

Reviewers:

(1) Ernest Eteng, Michael Okpara University of Agriculture, Nigeria. (2) Charles Bwalya Chisanga, Ministry of Agriculture and Livestock, Zambia. Complete Peer review History: http://www.sciencedomain.org/review-history/19943

Original Research Article

Received $5^{\text {th }}$ May 2017

Accepted $4^{\text {th }}$ July 2017

Published $8^{\text {th }}$ July 2017

\section{ABSTRACT}

The aim was to evaluate the suitability of the soils for the production of maize and to have a detailed soil database for effective land use planning. Soil requirements for maize were collected from past research works and compared with data obtained from the field survey. The study showed that the soils of the area had formed under climatic environment presently characterized by an annual rainfall of about $1330.20 \mathrm{~mm}$ and a mean annual temperature of about $27.80^{\circ} \mathrm{C}$. The soils of the upper slope were classified as Typic Paleustalfs, while those of the middle and lower slopes were classified as Typic Haplustalfs and Typic Kandiaqualfs respectively, using soil taxonomy. The soils were well drained to poorly drained. The clay content ranged from 7.20 to 29.30 , increasing with depth. Organic carbon was low $(0.47 \%)$ in the upland and relatively high $(0.86 \%)$ in the low land. The suitability assessment results showed that although, certain qualities or characteristics such as mean annual temperature, relative humidity and base saturation were optimum for maize cultivation, there was however, no highly suitable (S1) land for maize cultivation in the area. All the soils were classified into moderately suitable (S2f) subclass due to their low 
nutrients levels. UAMTRF I and II Units of the area were moderately suitable (S2tf) due to topography and low soil fertility. UAMTRF III was limited by its imperfect drainage to marginally suitable subclasses S3wf for maize production. To raise the productivity level of the lands for optimal maize production, management techniques such as continuous organic matter incorporation and mineral fertilizers application, and efficient use of mineral fertilizers with low levels of chemical inputs with adaption of appropriate irrigation techniques (in lowlands) would make dry season farming sustainable.

Keywords: Agriculture; maize; Makurdi; production; soil evaluation; suitability.

\section{INTRODUCTION}

The broad principles of land evaluation involve comparing the requirements of land use with quality of land thereby assessing the value of each type of land present for each land use [1]. Decisions on land use are being based on comprehensive analysis of the production and potentials of natural resources such as climate, soil and hydrology [2]. Soil evaluation is very important in this direction as it provides information on the potentials and constraints of land for a defined land use type in terms of crop performance as affected by the physical environment. Soil evaluations are based on knowledge of crop requirements, prevailing conditions and applied soil management methods [3]. Soil evaluation for suitability classification quantifies in broad terms to what extent soil conditions match crop requirements under a defined input and management [4]. Evaluating the soil enables optimum performance and maximum productivity of the crop. In evaluation, the specific crop requirements will be calibrated with the terrain and soil parameters [1] so that the identified limiting factors could be managed to suit crop requirements and improve productivity. Land evaluation thus, enables management guidelines in order to promote a more sustainable use of the soil and environmental resources [5].

Maize is an important cereal crop, which ranks third after wheat and rice in the world [6]. Maize is grown widely in many countries of the world. The pressing demand for food and space from a growing population has created a competition for land. In many developing countries, Nigeria inclusive, fuel-wood, cash crops, timber for construction and grazing for livestock compete with food crops for space, not only on the better quality land but also the marginal areas [7]. The major producers are United States of America, Brazil, France, India and Italy. In Africa, the bulk of maize produced is used as human food although it is increasingly been utilized for livestock feed. According to [8] data, the area planted to maize in West and Central Africa alone increased from 3.2 million in 1961 to 8.9 million hectares in 2001. This phenomenal expansion of the land area devoted to maize resulted in increased production from 2.4 million metric tonnes in 1961 to 10.6 million metric tonnes in 2001 [8].

In spite the increase in land area under maize production, yield is still low. Some of the major causes of low maize yield are declining soil fertility and insufficient use of fertilizers resulting in severe nutrient depletion of soils [9].

The interest of the farmer in the business of producing crops is mainly on how profitable it is to grow a particular crop and what amendments are necessary to optimize the productivity of the soil for the specified crop [10]. Thus, the solutions to the farmers' problems are largely dependent on the suitability studies of the land.

The study objective was to assess the potentials and limitations of climatic factors and soil properties in the suitability of some selected soils of Makurdi for maize production.

\section{MATERIALS AND METHODS}

\subsection{The Study Area}

The study was conducted at the Teaching and Research Farm of the University of Agriculture, Makurdi, which was about ten (10) hectares of land. The University lies northeast of Makurdi town, which is between latitude $7.450 \mathrm{~N}$ and $7.500 \mathrm{~N}$ and longitude $8.000 \mathrm{E}$, and 9.000E. Makurdi is in a strategic position in the agricultural map of Nigeria, producing a wide range of both annual and perennial crops such as yam, maize, rice, sorghum, groundnut, soybean, cowpea, citrus, mangoes, and a variety of vegetables: One of the factors responsible for this wide range of crops is the favourable climate [11]. 
Makurdi has tropical climate conditions with distinct wet and dry seasons. The dry season starts from November to March while the rainy season starts from April to October previous years. In the past, Benue state experienced a bimodal rainfall distribution pattern with one peak in July and another in September. Recent meteorological data points to unimodal pattern with the single peak in August. Mean annual rainfall for Benue state varies between 1000 and $1600 \mathrm{~mm}$.

The mean minimum air temperature of Makurdi is 16.20 to $17.20^{\circ} \mathrm{C}$ during the period of harmattan, which is December to February. The mean maximum air temperature is $37.7^{\circ} \mathrm{C}$ in March prior to the onset of rains. The slope of the area is 0 to 5 and the mean elevation above sea level is about $93 \mathrm{~m} \mathrm{[12]}$.

\subsection{Field Analysis}

Field studies involved digging of three (3) profile pits and morphological description of the profiles as well as the collection of bulk soil samples for laboratory analysis. The profile pits were dug based on the nature of the slope of the study areas. One pit was located at the crest, the second at the middle slope and the third at the foot slope to enhance proper study of the soils of the areas. Profile pits were described using guidelines from soil survey manual [13].

\subsection{Laboratory Studies}

Standard laboratory procedures were employed in the investigation of the physical and chemical characteristics of the soil samples collected from the field. The bulk soil samples collected from the field were air-dried. The air-dried samples were gently crushed using a mortar and pestle. The samples were sieved through2mm and $0.5 \mathrm{~mm}$ sieves and used for laboratory analyses. For laboratory analyses like particle size distribution, Boyoucos hygrometer method was used. Electrometric method as described by Hesse [14] was used for $\mathrm{pH}$ analysis. Walkley-Black method

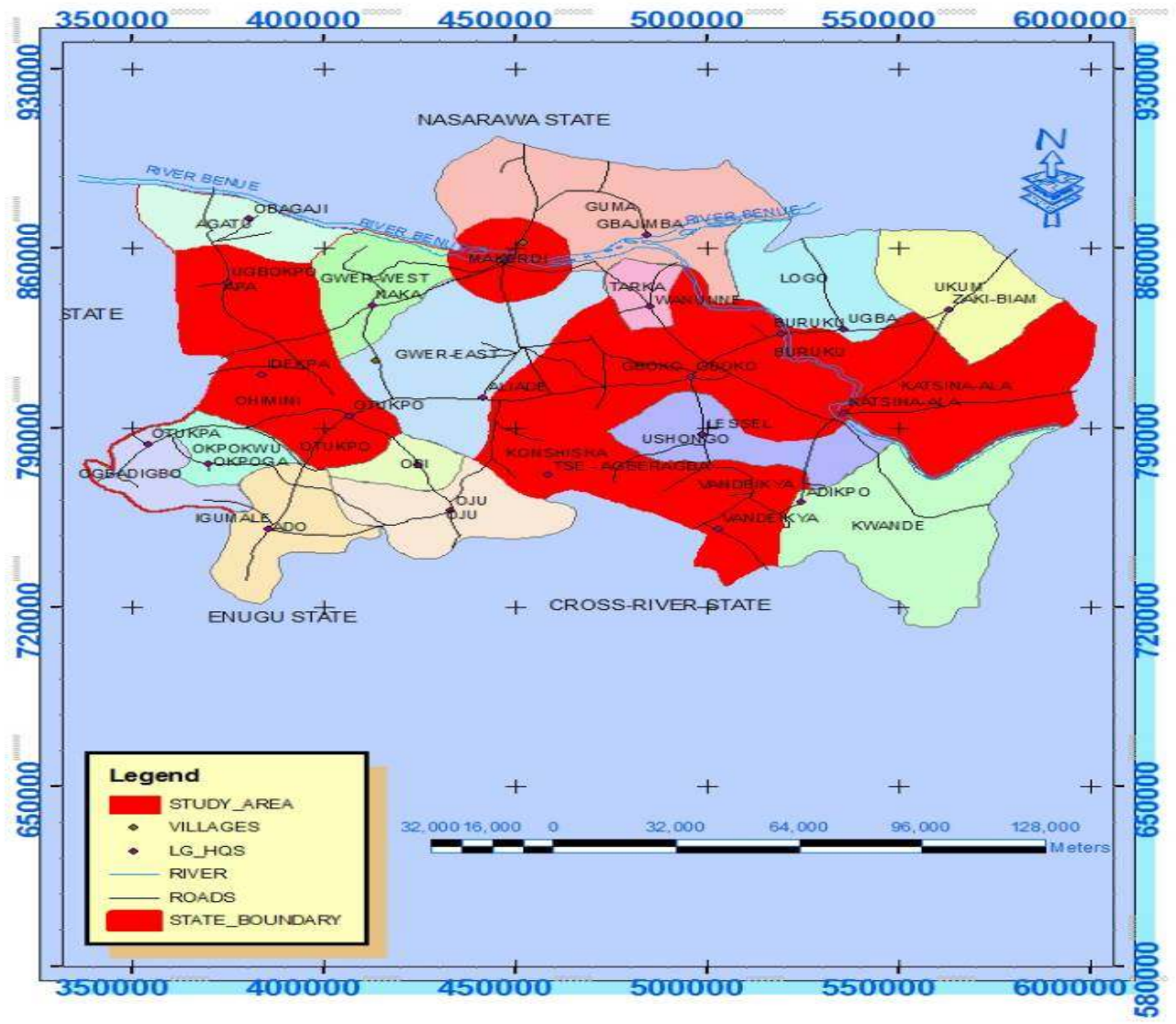

Fig. 1. Map of Benue State, Nigeria 


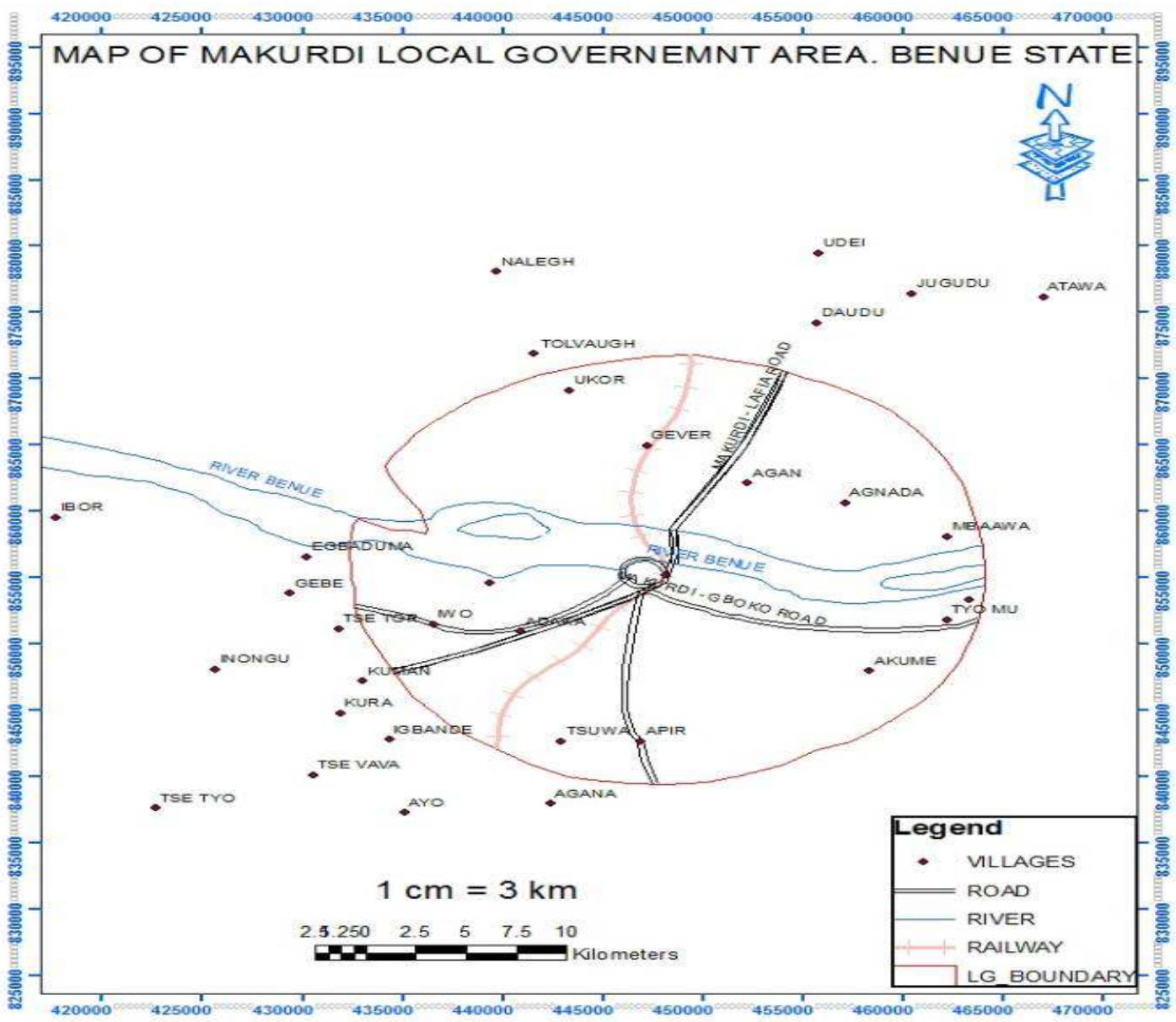

Fig. 2. Map of Makurdi local government area of Benue State

as described by Hesse [14] was used for organic carbon determination. Total nitrogen was determined by the use of macro Kjelidahl [15] methods. Sodium bicarbonate $\mathrm{NaHCO}_{3}$ extracting solution [16] was used for available phosphorus determination, and exchangeable cations ( $\mathrm{Ca}, \mathrm{Mg}, \mathrm{K}$ and $\mathrm{Na}$ ). Cation exchange capacity was also determined using neutral solution of ammonium acetate method.

\subsection{Land Evaluation Procedure}

The suitability evaluation of the land was done using the conventional parametric method [4]. Pedons were placed in suitability classes by matching their characteristics with the established requirements for maize (Table 1). The aggregate suitability class indicates the most limiting characteristics of the pedons. The parameters used for the land quality calculation include rainfall, mean annual temperature, slope, wetness, drainage. While those of soil characteristics included texture, coarse fragment, soil $\mathrm{pH}$. Other fertility indicators were base saturation, organic carbon and available phosphorus.

\section{RESULTS AND DISCUSSION}

\subsection{Physical Properties}

\subsubsection{Soil morphology}

Three soils mapping units were identified (UAMTRF I, UAMTRF II, and UAMTRF III) in the study area based on their morphological characteristics mainly: Texture, depth, colour, drainage, nature of underlying materials and surface characteristics. Topography was a prominent feature demarcating the soil boundaries (Table 2). 
Table 1. Land and soil requirements for suitability rating of maize (Zea mays L.)

\begin{tabular}{|c|c|c|c|c|c|}
\hline \multirow[t]{2}{*}{ Land characteristics } & Rate & $100-95$ & $84-40$ & $39-20$ & $19-0$ \\
\hline & Class & S1 & S2 & S3 & N1 \\
\hline \multicolumn{6}{|l|}{ Climatic (c) } \\
\hline \multirow[t]{2}{*}{ Annual Rainfall } & $\mathrm{mm}$ & $850-1250$ & $600-750$ & $500-600$ & - \\
\hline & & & $1600-1800$ & $>1800$ & - \\
\hline Mean Annual Max. Temp. & $\mathrm{oC}$ & $22-26$ & $18-16$ & $36-30$ & - \\
\hline Relative Humidity & $\%$ & $50-80$ & $>80$ & - & - \\
\hline Length of Dry Season & Days & $150-220$ & $110-130$ & $90-110$ & - \\
\hline $\begin{array}{l}\text { Topography }(t) \\
\text { Slope }\end{array}$ & $\%$ & $0-2$ & $4-8$ & $8-16$ & $>30-50$ \\
\hline Wetness (w) & & $0-4$ & $8-16$ & $16-30$ & $>30$ \\
\hline Flooding & Class & FO & $\mathrm{FI}$ & Aeric & Poor \\
\hline Drainage & Class & Good & Poor & Poor & Drainable \\
\hline \multicolumn{6}{|l|}{ Soil Physical Properties (s) } \\
\hline Texture / Structure & Class & $\mathrm{CL}, \mathrm{C}$ & LCS & $\mathrm{CS}, \mathrm{S}$ & $S$ \\
\hline Coarse Fragments $(0-50 \mathrm{~cm})$ & $\%$ & $<3$ & $15-35$ & $35-55$ & - \\
\hline \multicolumn{6}{|l|}{ Fertility (f) } \\
\hline CEC & $\begin{array}{l}\text { (cmol (+) } \\
\text { kg-1 clay) }\end{array}$ & $>24$ & $<16(-)$ & $<16(+)$ & - \\
\hline Base Saturation & $\%$ & $>50$ & $20-35$ & $<20$ & - \\
\hline $\mathrm{pH}$ & Water & $5.5-7.0$ & $5.0-8.0$ & $5.0-8.0$ & - \\
\hline Organic carbon (OM) & $(0-50) \%$ & $>2$ & $0.8-1.2$ & $<0.8$ & - \\
\hline Avail. $\mathrm{P}$ & mgkg-1 & $>22$ & $7-13$ & $3-7$ & $<3$ \\
\hline Extractable K & $\begin{array}{l}\mathrm{Cmol}(+) \\
\mathrm{kg}-1\end{array}$ & $>0.50$ & $0.20-0.30$ & $0.10-0.20$ & $<0.10$ \\
\hline Total nitrogen & $\%$ & $>0.15$ & $0.08-0.10$ & $0.04-0.08$ & $<0.08$ \\
\hline
\end{tabular}

\subsection{Soil Physical Characteristics}

\subsubsection{Soil particle size distribution}

The particle size distribution values for the soil mapping units are shown in Table 3 . The values revealed the sandy nature of all the soil units. Soils of units I and III generally have loamy sand surface texture while, soil unit II had sandy loam surface texture. The sand fraction of the three soil units ranged from 51.6 to $78.1 \%$. This high fraction of sand could be attributed to the nature of the parent material (sandstone). Sand fraction decreased with depth in all soil units. The clay content of the soils was moderate to high ranging from 7.2 to 29.3, while silt fraction ranged from 13.5 to $20.4 \%$. Because of illuviation, the clay content of the soils was higher in the subsurface horizons than at the surface.

\subsubsection{Soil structure}

The weak fine to medium crumbs of "A" horizon of all soil units (Table 2) could be attributed to their low level of organic matter and sandy nature of the soils. In the surface horizons, the three units had moderate to strong, medium to coarse sub-angular blocky structures. This may be attributed to the corresponding increase in clay content in the sub soils.

\subsection{Soil Chemical Characteristics}

\subsubsection{Soil reaction}

The $\mathrm{pH}$ (in water) of the soils ranged between 5.28 and 6.35 (Table 3) indicating strong to slightly acid [18]. However, most of the sub horizons were strongly acid in reaction. There was a general tendency among these soils to have higher $\mathrm{pH}$ values at surface, which decreased with depth. Ojanuga [12] attributed the slightly higher $\mathrm{pH}$ in the upper most soil horizon to the accumulation of exchangeable calcium $(\mathrm{Ca})$ and magnesium $(\mathrm{Mg})$ derived from plant roots and litter decomposition, as well as biogenetic cycling of bases. The $\mathrm{pH}$ values of the soil units I and III were higher than those of Unit II. As the cations are leached, hydrogen ion $\left(\mathrm{H}^{+}\right)$ from water $\left(\mathrm{H}_{2} \mathrm{O}\right)$ replaces the leached cations in the exchange complex to balance the charge. Soil acidity is known to affect most soil nutrients especially $\mathrm{P}, \mathrm{N}, \mathrm{S}$ and micronutrients [19]. 
Table 2. Soil morphological characteristics

\begin{tabular}{|c|c|c|c|c|c|c|c|}
\hline Toposequence & Horizon & Depth (cm) & Colour & Mottles & Texture & Structure & Boundary \\
\hline \multirow[t]{5}{*}{ UAMTRF I } & A & $0-22$ & 10 YR5/3 & - & LS & $1 \mathrm{Fcr}$ & Gs \\
\hline & B & $22-51$ & 7.5 YR6/2 & - & SL & $2 \mathrm{Mcr}$ & ds \\
\hline & $\mathrm{BC}$ & $51-88$ & 5 YR5/8 & - & SL & 2MSbk & ds \\
\hline & C1 & $88-112$ & 10 YR6/6 & - & SL & 2Msbk & gs \\
\hline & $\mathrm{C} 2$ & $112-146$ & 7.5 YR8/0 & 2.5YR $4 / 3$ & $\mathrm{SCL}$ & 2 csbk & - \\
\hline \multirow[t]{4}{*}{ UAMTRF II } & A & $0-30$ & 10 YR5/6 & - & SL & $1 \mathrm{Fcr}$ & Ds \\
\hline & B1 & $30-73$ & 7.5 YR6/4 & - & SL & $2 \mathrm{Mcr}$ & gs \\
\hline & B2 & $73-101$ & 10YR6/4 & - & SL & 3Csbk & $d w$ \\
\hline & C & $101-124$ & 10YR8/4 & $5 Y R 5 / 3$ & $\mathrm{CL}$ & 3Csbk & \\
\hline \multirow[t]{5}{*}{ UAMTRF III } & A & $0-49$ & 10YR5/6 & - & LS & $1 \mathrm{Fcr}$ & Ds \\
\hline & B1 & $49-74$ & 10YR8/4 & - & LS & $2 \mathrm{Mcr}$ & gs \\
\hline & B2 & $74-103$ & 10YR7/4 & - & $\mathrm{SCL}$ & 2Msbk & gs \\
\hline & $\mathrm{C} 1$ & $103-130$ & 7.5YR5/6 & 10YR8/5 & $\mathrm{SCL}$ & 3Csbk & ds \\
\hline & $\mathrm{C} 2$ & $130-145$ & 7.5YR8/10 & 10YR $5 / 6$ & $\mathrm{SCL}$ & 3Csbk & - \\
\hline
\end{tabular}

Table 3. Physical and chemical characteristics of the soils

\begin{tabular}{|c|c|c|c|c|c|c|c|c|c|c|c|c|c|c|c|c|c|}
\hline \multirow[t]{2}{*}{ TP. } & \multirow[t]{2}{*}{ Horizon } & \multirow{2}{*}{$\begin{array}{l}\text { Depth } \\
\text { (cm) }\end{array}$} & \multicolumn{3}{|c|}{ Mechanical analysis } & \multicolumn{2}{|c|}{ Soil pH } & \multirow{2}{*}{$\begin{array}{l}\text { O.C } \\
--.\end{array}$} & \multirow{2}{*}{$\begin{array}{l}\text { O.M } \\
\text { N (\%) }\end{array}$} & \multirow{2}{*}{$\begin{array}{l}\text { Total } \\
\end{array}$} & \multirow{2}{*}{$\begin{array}{l}\text { Avail.P } \\
\text { mgkg }^{-1}\end{array}$} & \multicolumn{4}{|c|}{ Exchangeable cations $(\mathrm{cmol}(+) / \mathbf{k g})$} & \multirow{2}{*}{$\begin{array}{l}\text { CEC } \\
\text { (cmol } \\
(+) / k g)\end{array}$} & \multirow{2}{*}{$\begin{array}{l}\text { B.S } \\
\text { (\%) }\end{array}$} \\
\hline & & & $\begin{array}{l}\text { Sand } \\
\text { / }\end{array}$ & $\begin{array}{l}\text { Silt --- } \\
\%-\end{array}$ & Clay & $\begin{array}{l}\mathrm{H}_{2} \mathrm{O} \\
1: 1\end{array}$ & $\begin{array}{l}\mathrm{KCl} \\
1: 1\end{array}$ & & & & & $\mathrm{Ca}$ & Mg & $\mathrm{K}$ & $\mathrm{Na}$ & & \\
\hline \multirow[t]{5}{*}{ Pit I } & A & $0-22$ & 78.1 & 13.5 & 8.4 & 6.35 & 5.37 & 1.47 & 2.53 & 0.094 & 4.21 & 3.15 & 1.60 & 0.30 & 0.12 & 5.30 & 97.54 \\
\hline & B & $22-51$ & 62.8 & 19.0 & 15.2 & 5.83 & 5.16 & 0.63 & 1.09 & 0.080 & 4.11 & 3.60 & 1.90 & 0.25 & 0.11 & 6.20 & 94.51 \\
\hline & $\mathrm{BC}$ & $51-88$ & 61.4 & 18.5 & 19.1 & 5.58 & 4.90 & 0.59 & 1.02 & 0.080 & 3.70 & 4.50 & 2.80 & 0.19 & 0.09 & 8.50 & 89.17 \\
\hline & $\mathrm{C} 1$ & $88-112$ & 58.6 & 15.1 & 26.3 & 5.46 & 4.70 & 0.51 & 0.88 & 0.070 & 3.38 & 5.40 & 3.07 & 0.23 & 0.09 & 9.40 & 93.51 \\
\hline & $\mathrm{C} 2$ & $112-146$ & 55.3 & 16.0 & 28.7 & 5.37 & 4.55 & 0.47 & 0.81 & 0.065 & 2.80 & 5.70 & 3.39 & 0.26 & 0.10 & 10.3 & 91.74 \\
\hline \multirow[t]{4}{*}{ Pit II } & A & $0-30$ & 68.2 & 17.3 & 14.5 & 5.61 & 4.80 & 0.74 & 1.28 & 0.077 & 3.97 & 3.66 & 1.78 & 0.34 & 0.070 .07 & 6.72 & 87.05 \\
\hline & B1 & $30-73$ & 67.7 & 18.1 & 16.2 & 5.39 & 4.40 & 0.68 & 1.18 & 0.071 & 3.42 & 3.09 & 1.98 & 0.30 & 0.07 & 7.60 & 71.57 \\
\hline & B2 & $73-101$ & 62.2 & 20.2 & 17.6 & 5.32 & 4.33 & 0.60 & 1.03 & 0.066 & 2.70 & 4.70 & 2.50 & 0.25 & 0.06 & 8.50 & 88.47 \\
\hline & C & $101-124$ & 61.5 & 20.4 & 19.1 & 5.28 & 4.29 & 0.51 & 0.88 & 0.060 & 2.20 & 4.95 & 2.90 & 0.19 & & 9.30 & 87.09 \\
\hline \multirow[t]{5}{*}{ Pit III } & A & $0-49$ & 77.3 & 15.4 & 7.2 & 6.24 & 5.70 & 0.86 & 1.48 & 0.101 & 4.26 & 2.75 & 0.90 & 0.16 & 0.08 & 4.80 & 80.20 \\
\hline & B1 & $49-74$ & 75.4 & 16.1 & 8.5 & 6.20 & 5.56 & 0.77 & 1.33 & 0.096 & 3.66 & 2.90 & 1.10 & 0.14 & 0.08 & 5.60 & 75.35 \\
\hline & B2 & $74-103$ & 57.5 & 17.3 & 24.2 & 6.16 & 5.43 & 0.70 & 1.21 & 0.062 & 3.38 & 6.60 & 3.57 & 0.11 & 0.07 & 12.8 & 80.85 \\
\hline & C1 & $103-130$ & 54.0 & 18.2 & 27.8 & 6.10 & 5.05 & 0.62 & 1.07 & 0.059 & 2.60 & 6.90 & 3.80 & 0.12 & 0.07 & 13.5 & 80.66 \\
\hline & $\mathrm{C} 2$ & $130-145$ & 51.6 & 19.1 & 29.3 & 5.35 & 4.66 & 0.56 & 0.97 & 0.054 & 2.40 & 7.80 & 4.40 & 0.90 & 0.06 & 15.7 & 83.82 \\
\hline
\end{tabular}




\subsubsection{Organic carbon}

Percentage organic carbon was low to moderate with values ranging from $0.47 \%$ to $1.47 \%$ (Table $3)$. These values decreased with depth in all the three Soil Units due to the concentration of plant roots and residue on the soils. The low organic carbon content of these soil units could be attributed to annual bush burning in the area as well as the native vegetation cover and climate. Drainage appeared to have strong influence on the organic matter content of the soil.

Earthworms and other organic fauna increase organic carbon content of the soil by breaking and biochemically altering fresh organic matter through mixing with inorganic materials and later excreting them to form a moist homogenous blend of the organic and mineral matters, which prevents rapid loss of humic compounds [20]. More earthworm casts were seen on the surface of soil unit III (UAMTRF III) in the upper slope than units I (UAMTRF I) and II (UAMTRF II) which are on the crest and middle slope respectively.

\subsubsection{Total nitrogen}

Total nitrogen values ranged from 0.101 to $0.54 \%$ (Table 3 ) for all the horizons of the profiles studied. The distribution of total nitrogen follows the same pattern as organic carbon both in profile distribution as well as on the top sequence.

Jones [21] revealed that savannah soils are generally low in total nitrogen. This is due to the low percentage of organic carbon content because the two are closely related. It is high where organic matter is high from the established relationship between soil organic carbon and nitrogen. It is obvious that climate, vegetation and human activities contribute to the low level of nitrogen.

\subsubsection{Available phosphorus (P)}

The soils generally had low levels of available phosphorus, which had values from 2.20 to 4.26 $\mathrm{mg} / \mathrm{kg}$ (Table 3). The surface horizons of the soils have the highest amount of available phosphorus, which decreased with soil depth. This shows that much of the available $P$ is in organic forms associated with organic matter.

\subsubsection{Exchangeable cations}

The values of exchangeable cations $(\mathrm{Ca}, \mathrm{Mg}, \mathrm{K}$ and $\mathrm{Na}$ ) were low in all the soil units (Table 3 ).
The low values of exchangeable bases of these soils maybe due to intensity of weathering and lateral translocation of bases. The amount of exchangeable calcium $(\mathrm{Ca})$ ranged between 2.71 and $7.8 \mathrm{cmol}(+) / \mathrm{kg}$ of soil. Magnesium $(\mathrm{Mg})$ ranged between 0.90 and $4.40 \mathrm{cmol}(+) / \mathrm{kg}$ of soil. Potassium $(\mathrm{K})$ ranged between 0.11 and $0.90 \mathrm{cmol}(+) / \mathrm{kg}$ of soil while Sodium $(\mathrm{Na})$ ranged between 0.06 and $0.12 \mathrm{cmol}(+) / \mathrm{kg}$ of soil. The predominance of $\mathrm{Ca}$ over the other cations in these soils may be because of all the exchangeable cations, $\mathrm{Ca}$ is least easily lost from the soil environment [22].

\subsubsection{Cation exchange capacity}

The CEC of the soil ranged from 4.8 to 15.7 $\mathrm{cmol}(+) / \mathrm{kg}$ of soil (Table 3). The lowest CEC values were recorded in "A" horizon of unit III owing to their low organic matter content and perhaps low clay content. Donahue [23] reported that some sandy soils of the tropics with dominant sesquioxide clay might have low CEC hence, low fertility.

\subsubsection{Base saturation}

Base saturation by sum of cations ranged between 71.57 and $95.54 \%$ (Table 3) which is rated very high [24]. The high base status showed that the soils had high native fertility, which is confirmed by the luxuriant growth of the vegetation of the soil.

\subsection{Land Suitability Evaluation}

The overall methodology followed involved the selection of attributes relevant to maize production, generation of data layers, weighting and overlaying of the data layers to generate a land suitability map for maize production. Data sets for topographic variables were generated from the digital evaluation model (DEM) using various algorithms in ArcGIS software. Elevation dataset was used as proxy for climatic variables (rainfall and temperature) and it was generated by reclassifying the DEM. The distance dataset representing accessibility was generated using the Euclidean distance tool. Each data layer was reclassified into suitability classes based on maize requirement. The suitability levels assigned to each dataset were defined based on literature, expert knowledge, observation and practical experiences. The suitability levels were ranked as highly suitable, suitable, moderately suitable, marginally suitable, currently not suitable and permanently not suitable based on 
the suitability classification structure of the [17]. The datasets generated were finally combined using the weighted sum overlay to generate the land suitability map for rain fed maize production.

The matching of land characteristics used for suitability ratings of sites for maize (Zea mays L.) production in Makurdi (Table 4) with land and soil requirements for suitability rating of maize (Table 1) resulted in the suitability classes of the soil mapping units as shown in Fig. 3. The region was optimal or near optimal in mean annual temperature, relative humidity, length of dry season, slope and base saturation. Textural classes of the UAMTRF I soils ranged from loamy sand to sandy loam, thus, considered moderately suitable (S2s) for the cultivation of maize. The soil texture for optimum maize performance is clay loam or loam [25]. However, topography and low soil fertility levels limited the soils into the moderately suitable (S2tf) subclass for maize production. Drainage status of UAMTRF III reduced its suitability for maize cultivation to marginally suitable (S3wf) subclass. These qualities have lowered the suitability of
UAMTRF III pedons to marginally suitable subclass S3tf and S3wf for the cultivation of maize. Imperfect drainage status of pedons UAMTRF II has reduced its productivity to moderately suitable class (S2). Based on these assessments, none of the pedons was considered highly suitable for maize cultivation in the area. Soils of UAMTRF I and II were classified into moderately suitable (S2f) subclass as a result of their low nutrients status.

\subsection{Statistical Analysis of Chemical Properties of Soils of UAMTRF I, UAMTRF II and UAMTRF III Units of the Study Area (One-Sample Test)}

The results of the soil chemical properties of the study area for UAMTRF I, II and III units were subjected to t-Test (One-Sample Test) and the result presented in Table 6 . The result indicated that there was no significant difference between soils of UAMTRF I and II, but there was significant difference between UANTRF I and III.

Table 4. Land characteristics used for suitability ratings of sites for maize (Zea mays L.) production in Makurdi

\begin{tabular}{|c|c|c|c|c|}
\hline Land characteristics & Unit & UAMTRF I & UAMTRF II & UAMTRF III \\
\hline \multicolumn{5}{|l|}{ Climatic (c) } \\
\hline Annual Rainfall & $\mathrm{Mm}$ & $1000-1600$ & $1000-1600$ & $1000-1600$ \\
\hline Mean Annual Max. Temp. & $\mathrm{C}$ & 37.70 & 37.70 & 37.70 \\
\hline Relative Humidity & $\%$ & $>80$ & $>80$ & $>80$ \\
\hline Length of Dry Season & Days & $150-220$ & $150-220$ & $150-220$ \\
\hline \multicolumn{5}{|l|}{ Topography (t) } \\
\hline Slope & $\%$ & $0-5$ & $0-4$ & $0-3$ \\
\hline Wetness (w) & W & & & \\
\hline Flooding & Class & $\mathrm{FO}$ & FR & $\mathrm{FI}$ \\
\hline Drainage & Class & WD & WD & ID \\
\hline \multicolumn{5}{|l|}{ Soil physical properties (s) } \\
\hline Texture / Structure & Class & 95 & 90 & 80 \\
\hline Coarse Fragments $(0-50 \mathrm{~cm})$ & $\%$ & $<3$ & $15-35$ & $35-55$ \\
\hline \multicolumn{5}{|l|}{ Fertility (f) } \\
\hline CEC & $\begin{array}{l}(\mathrm{cmol}(+) / \mathrm{kg} \\
\text { clay) }\end{array}$ & 7.94 & 8.03 & 10.48 \\
\hline Base Saturation & $\%$ & 93 & 82 & 79 \\
\hline $\mathrm{pH}$ & Water & $5.5-7.0$ & $5.0-8.0$ & $5.0-8.0$ \\
\hline Organic matter (OM) & $(0-50) \%$ & 1.27 & 1.09 & 1.21 \\
\hline Avail. P & $\mathrm{cmol}(+) / \mathrm{kg}$ & 3.64 & 3.07 & 3.26 \\
\hline Extractable K & $\mathrm{cmol}(+) / \mathrm{kg}$ & 0.25 & 0.27 & 0.29 \\
\hline Total nitrogen & $\%$ & 0.078 & 0.069 & 0.074 \\
\hline
\end{tabular}




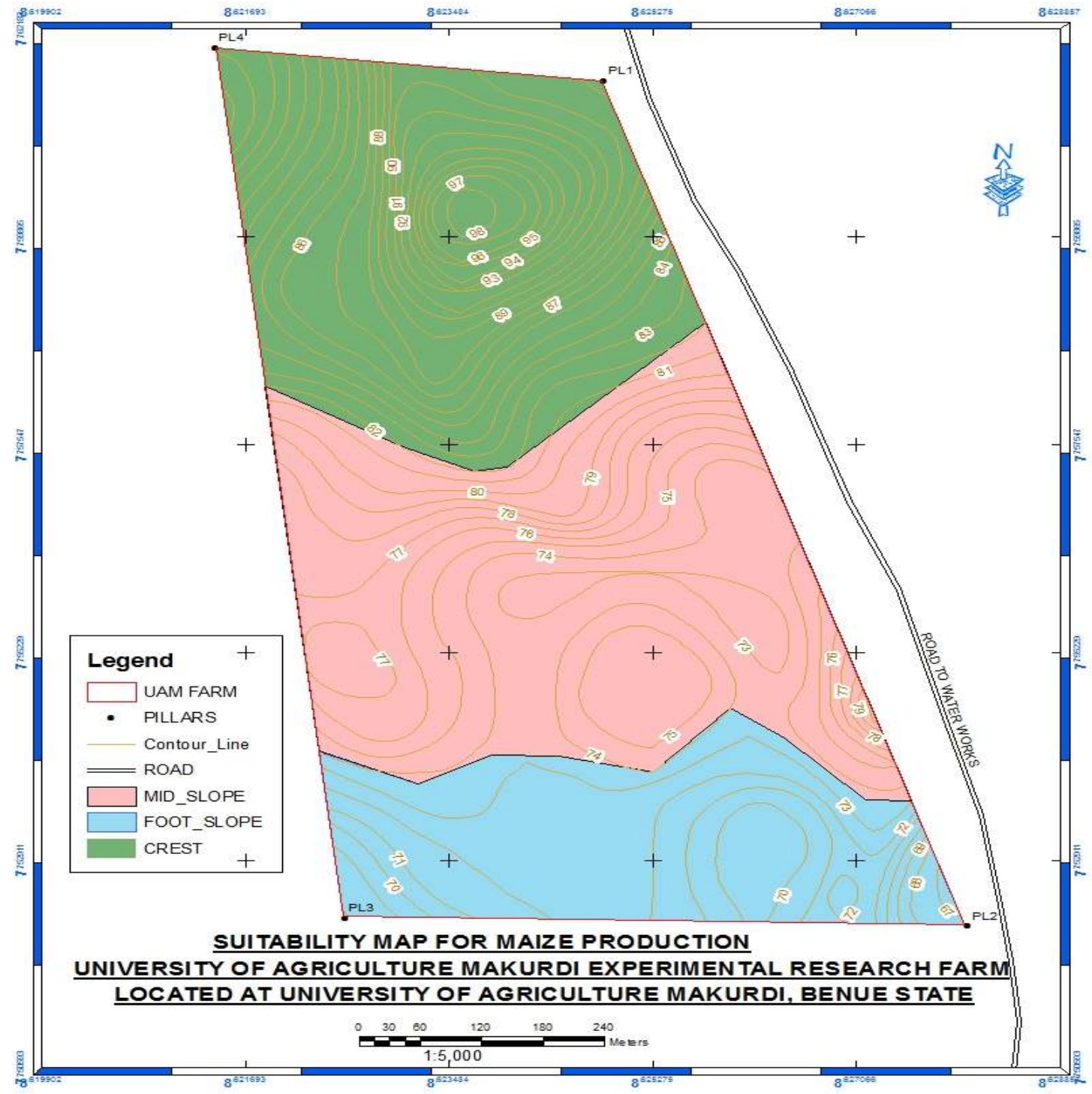

Fig. 3. Suitability Map for maize production in UAMTRF Benue State

Table 5. Land characteristics used for suitability ratings of sites for maize (Zea mays L.) production in Makurdi

\begin{tabular}{|c|c|c|c|}
\hline Land characteristics & UAMTRF I & UAMTRF II & UAMTRF III \\
\hline \multicolumn{4}{|l|}{ Climatic (c) } \\
\hline Annual Rainfall & $100=S 1$ & $100=S 1$ & $100=S 1$ \\
\hline Mean Annual Max. Temp. & $100=S 1$ & $100=S 1$ & $100=S 1$ \\
\hline Relative Humidity & $100=S 1$ & $100=S 1$ & $100=S 1$ \\
\hline Length of Dry Season & $100=S 1$ & $100=\mathrm{S} 1$ & $100=S 1$ \\
\hline \multicolumn{4}{|l|}{ Topography (t) } \\
\hline Slope & $80=\mathrm{S} 2$ & $84=\mathrm{S} 2$ & $95=\mathrm{S} 1$ \\
\hline \multicolumn{4}{|l|}{ Wetness (w) } \\
\hline Flooding & $100=S 1$ & $85=\mathrm{S} 2$ & $71=\mathrm{S} 3$ \\
\hline Drainage & $95=\mathrm{S} 1$ & $75=S 2$ & $65=S 3$ \\
\hline
\end{tabular}




\begin{tabular}{llll}
\hline Land characteristics & UAMTRF I & UAMTRF II & UAMTRF III \\
\hline Soil Physical Properties (s) & & & \\
Texture / Structure & $95=\mathrm{S} 1$ & $90=\mathrm{S} 2$ & $80=\mathrm{S} 3$ \\
$\begin{array}{l}\text { Coarse Fragments(0-50cm) } \\
\text { Fertility (f) }\end{array}$ & $90=\mathrm{S} 2$ & $90=\mathrm{S} 2$ & $90=\mathrm{S} 2$ \\
CEC & $65=\mathrm{S} 3$ & $69=\mathrm{S} 3$ & $71=\mathrm{S} 3$ \\
Base Saturation & $93=\mathrm{S} 1$ & $82=\mathrm{S} 1$ & $79=\mathrm{S} 1$ \\
$\mathrm{pH}$ & $90=\mathrm{S} 1$ & $80=\mathrm{S} 2$ & $38=\mathrm{S} 3$ \\
Organic matter (OM) & $84=\mathrm{S} 2$ & $75=\mathrm{S} 2$ & $80=\mathrm{S} 2$ \\
Avail. P & $65=\mathrm{S} 3$ & $70=\mathrm{S} 3$ & $15=\mathrm{S} 3$ \\
Extractable K & $75=\mathrm{S} 2$ & $80=\mathrm{S} 2$ & $54=\mathrm{S} 3$ \\
\hline \multicolumn{2}{r}{ Aggregate suitability class } & S2tf & S2tf \\
\hline \multicolumn{2}{c}{ UAMTRF-University of Agriculture Makurdi Teaching and Research Farm } \\
\hline
\end{tabular}

FO - No Flooding, FI - Seasonal Flooding, FR - Flooding Rare; WD- Well Drained, ID-Poorly Drained

Table 6. Statistical analysis of chemical properties of soils of UAMTRF I, UAMTRF II and UAMTRF III units of the study area (One-sample test)

\begin{tabular}{lllllll}
\hline & \multicolumn{3}{c}{ Test value = 0 } \\
\cline { 2 - 5 } & $\mathbf{T}$ & Df & $\begin{array}{l}\text { Sig. } \\
\text { (2-tailed) }\end{array}$ & $\begin{array}{l}\text { Mean } \\
\text { difference }\end{array}$ & \multicolumn{2}{c}{$\begin{array}{c}\text { 95\% confidence interval of the } \\
\text { difference }\end{array}$} \\
\cline { 5 - 7 } & & & & & Lower & Upper \\
\hline $\mathrm{pH}\left(\mathrm{H}_{2} 0\right)$ & 49.878 & 11 & .000 & 6.009167 & 5.74400 & 6.27433 \\
$\mathrm{OC}$ & 11.559 & 11 & .000 & .938333 & .75966 & 1.11701 \\
$\mathrm{OM}(\%)$ & 8.925 & 11 & .000 & 1.514167 & 1.14077 & 1.88757 \\
$\mathrm{~N}$ & 19.838 & 11 & .000 & .043917 & .03904 & .04879 \\
$\mathrm{Ca}^{2+}$ & 15.744 & 11 & .000 & 2.943750 & 2.53221 & 3.35529 \\
$\mathrm{Mg}^{2+}$ & 8.341 & 11 & .000 & 2.255833 & 1.66055 & 2.85111 \\
$\mathrm{Na}^{+}$ & 22.269 & 11 & .000 & .235000 & .21177 & .25823 \\
$\mathrm{~K}^{+}(\mathrm{cmol}(+) / \mathrm{kg})$ & 8.109 & 11 & .000 & .256250 & .18670 & .32580 \\
$\mathrm{E} . \mathrm{A}$ & 6.752 & 11 & .000 & .869583 & .58614 & 1.15303 \\
$\mathrm{CEC}$ & 14.086 & 11 & .000 & 8.660417 & 7.30721 & 10.01363 \\
$\mathrm{ECEC}$ & 11.380 & 11 & .000 & 6.852500 & 5.52713 & 8.17787 \\
$\mathrm{BS}(\%)$ & 54.315 & 11 & .000 & 65.982083 & 63.30830 & 68.65587 \\
$\mathrm{ESP}(\%)$ & 6.336 & 11 & .000 & 3.069167 & 2.00296 & 4.13537 \\
$\mathrm{Av} . \mathrm{P}$ & 80.659 & 11 & .000 & 4.548750 & 4.42463 & 4.67287 \\
$(\mathrm{ppm})$ & & & & & & .90412 \\
$\mathrm{SAR}$ & 1.593 & 11 & .140 & .379583 & -.14496 & \\
\hline
\end{tabular}

\section{CONCLUSION}

The paper offered some valuable insight with outcomes vital to maize production in Benue State of Nigeria. The significance of the study is characterized by its novelty as a pathway of efficient management based on the following findings (a) improved decision support tools for managers in crop production; (b) identification of limiting factors influencing agricultural activities; (c) emergence of novel index for crop management. These are expected to result in increased benefits through best management practices in decision-making. For an increase in the productivity levels of these lands for optimum maize production, it is therefore recommended that, farm management techniques that improve soil nutrient levels and structures be practiced.
The suitability assessment results showed that although, certain qualities or characteristics such as mean annual temperature, relative humidity and base saturation were optimum for maize cultivation, there was however, no highly suitable (S1) land for maize cultivation in the area. Soils of UAMTRF I and II were classified into moderately suitable (S2f) subclass, and marginally suitable due to their low nutrients levels. UAMTRF I and II Units of the area were moderately suitable (S2tf) due to topography and low soil fertility. UAMTRF III was limited by its imperfect drainage to marginally suitable subclasses S3wf for maize production. It can further be concluded that the generated land suitability map with overall classification accuracy of $73 \%$ (UAMTRF । $42.5 \%$ and UAMTRF II $30.5 \%$ which was about 7.3 hectares of the total 
10 hectares of the farm land) can rightly be used as a guide in decision making for maize production.

\section{COMPETING INTERESTS}

Authors have declared that no competing interests exist.

\section{REFERENCES}

1. Dent D, Young A. Soil survey and land evaluation. George Alien and Unwin Ltd., London, UK; 1981.

2. Abagyeh SOI, Idoga S, Agber PI. Land suitability evaluation for maize (Zea mays L) production in selected sites of the MidBenue valley, Nigeria. Int. J. Agric. Pol. Res. 2016;4(3):46-51.

3. Ande OT. Soil suitability evaluation and management for cassava production in the Derived Savannah Area of South-western Nigeria. Int. J. Soil Sci. 2011;6:142149.

4. Food and agriculture organisation. A frame work for land evaluation. FAO Soils Bull. 32: FAO, Rome. 1976;87.

5. Maniyunda LM, Malgwi WB, Yaro DT. Evaluation of the suitability of Galma River basin for irrigated agriculture. Proceedings of the $31^{\text {st }}$ Annual Conference of Soil Science Society of Nigeria. $13^{\text {th }}-17^{\text {th }}$ Nov. 2006, ABU Zaria Nigeria. 2007;23-28.

6. David and Adams. Crops of drier regions of the tropics. Longman Publishing Limited, Singapore. 1985;92-98.

7. Verheye WH. Land use and land covervol. 2- Land- Evaluation, Encyclopedia of Life Support Systems (EOLSS); 2000.

8. Food and agriculture organisation. ViewsFood Crops and Storage. 2002;(1):1-10.

9. Christina GH. Gender and soil fertility in Africa: An introduction. Afr. Studies Q., (In press). Company, New York. 2002;639.

10. Fasina AS, Adeyanju S. Suitability classification of some granitic soils of humid west Nigeria for rain fed maize, cassava and swap rice production. Niger. J. Soil Sci. 2006;16:1-9.

11. Igomu EA, Idoga $S$. Evaluation of soils for cowpea (Vigna unguiculata L.) production: A case study of siwes farms of University of Agriculture Makurdi. IJPSS. 2017; 15(3): 1-8.
12. Ojanuga AG, Ekwoanya MA. Temperal changes in land uespatern in Benue River flood plain and adjoining uplands at Makurdi, Nigeria, In: L. Theombiano maintaining soils in the environment with remote sensing and proceeding of the ISSS international symposium onagadongon Burkina faso. 1995;418.

13. Soil survey staff. Key to soil taxonomy, 11 Edition. Basic system of soil classification for making and interpreting soil survey, national reserve conservation services, agricultural department, soil survey Division. Washingston DC USA sorghum Hp3 variety. In; 2010. Asadu CLA, Ezeaku PI, Uzoh MI Unagwu B. (eds) Soil resource management, global climate change and food security. Proceedings of the $36^{\text {th }}$ annual conference of Soil Science Society of Nigeria held at the University of Nigeria, Nsukka. 2012;268-275.

14. Hesse RP. A textbook of soil chemical analysis. John Murray Publishesrs Ltd. London; 1971.

15. Bremmer JM. Total nitrogen in C. A. black (ed) methods of soils analysis. Part 2 agron of American Soc. Agron. Madison Wisconsin; 1965.

16. Olsen RS, Dean AL. Available phosphorus in C. A. Black (ed) method of soil analysis part 2. Aron 9. American Soc. Agron. Madison, Wisc. USA; 1965.

17. Adesemuyi EA. Suitability assessment of soils for maize (Zea mays) production in a humid tropical area of South-western Nigeria. Int. J. Adv. Res. 2014;1(2):538546.

18. United States Department of Agriculture. Soil Survey Manual; 1951.

19. Agbede OO. Understanding soil and plant Nutrition. $1^{\text {st }}$ Edition, Keffi, Nassarawa State, Salman Press and Co. Nigeria Ltd; 2009

20. Esu IE. Evaluation of soils for irrigation in the Kaduna area of Nigeria, Unpubl. Ph.D thesis A. B. U Zaria. 1982;171.

21. Jones MJ. The organic matter content of the savannah soils of West Africa. Journal of Soil Science. 1973;24:24-53.

22. Brady MC. The nature and properties of soils. $8^{\text {th }}$ ed. Macmillan Publishing Company, New York. 1974;639.

23. Donahue RL, et al. Our soil and their management publ. Interstate printers and publishers inc. Danville, Illinoios; 1976. 
24. Idoga S. Ibrahim NB. Effect of soil acidity on root growth and development of sorghum Hp3 variety. In: Asadu CLA, Ezeaku PI, Uzoh MI, Unagwu B. (eds) Soil resource management, global climate change and food security. Proceedings of the $36^{\text {th }}$ annual conference of soil science society of Nigeria held at the University of Nigeria, Nsukka. 2012;268-275.

25. Sys C. Land Evaluation, Part I-III. Publication No 7 of the General Administration of Cooperative Development. Place de champs de Mars 5, biote 57, 1050. 1985;247.

(0) 2017 Odoemena and Igomu; This is an Open Access article distributed under the terms of the Creative Commons Attribution License (http://creativecommons.org/licenses/by/4.0), which permits unrestricted use, distribution, and reproduction in any medium, provided the original work is properly cited.

Peer-review history:

The peer review history for this paper can be accessed here: http://sciencedomain.org/review-history/19943 